\title{
METHODOLOGY FOR INCREASING THE COMPETENCES OF HOUSING MANAGERS IN CLIMATE CHANGE ISSUES
}

\author{
I. Geipele ${ }^{1 *}$, A. Kundzina ${ }^{1}$, L. Jansons ${ }^{1,2}$ \\ ${ }^{1}$ Riga Technical University, \\ Institute of the Civil Engineering and Real Estate Economics \\ 6 Kalnciema Str., Riga, LV-1048, LATVIA \\ 1,2Institute of Physical Energetics \\ 11 Krīvu Str., Riga, LV-1006, LATVIA \\ *e-mail: Ineta.Geipele@rtu.Iv
}

In order to identify the necessary competences and develop the study course programme, within the framework of the EUKI (The European Climate Initiative; Die Europäische Klimaschutzinitiative) project "From Housing Manager to CLImate Manager", research [1] has been conducted, describing the Latvian residential fund, analysing the principles and activities of multi-apartment residential buildings, as well as identifying and describing the parties involved in shaping the housing policy. Special attention is paid to energy efficiency issues for buildings - looking at Latvia's potential for climate changes, analysing energy consumption in buildings in relation to energy efficiency requirements, as well as assessing the medium and long-term objectives of buildings in Latvia and the obstacles to achieving them.

In order to clarify more precisely the necessary competences of housing managers for the successful implementation of the residential renovation process, a survey has been carried out for stakeholders in the project. Based on an analysis of the situation and the performed survey results, a methodology has been developed to increase the competences of housing managers in relation to the renovation of residential buildings in order to mitigate climate change.

Keywords: Climate changes, energy efficiency, housing policy, housing management. 


\section{INTRODUCTION}

The Latvian National Development Plan for 2021-2027 states that energy saving and sustainable use of resources are the responsibility of society in building a sustainable life environment and ensuring a circular economy. Significant energy savings can be achieved by introducing more efficient GHG reduction measures to increase the energy efficiency of buildings and improve heat resilience [2].

Management of multi-apartment residential houses (MARH), including energy efficiency issues, concerns both residents and owners of MARH and the interests of individual residential areas, as well as the state interests in general.

In 2019, Latvia took the first place in Europe by number of residents living in apartments (according to Eurostat, $65.9 \%$ of all Latvian residents, and even $88.1 \%$ in cities [3], thus sustainable planning for managing MARH is considered to be a significant spotlight at both national and local levels.

For a given moment, only a small proportion of residential houses comply with modern energy efficiency requirements, so it is necessary to take measures to encourage renovation of these buildings.

In order to improve the situation in the MARH management and reduce its negative impact on climate changes, the CLIMA project - From Housing Manager to CLImate Manager is being implemented from October 2020 to March 2023 within the framework of the European Climate Initiative (EUKI) programme. The EUKI is a project with a financing instrument by the German Federal Ministry for the Environment, Nature Conservation and Nuclear Safety (BMU).
The project participants are:

- Energy Conservation Foundation (FPE) - leading partner, Poland;

- Housing Initiative for Eastern Europe (IWO) - project partner, Germany;

- Riga Technical University (RTU) project partner, Latvia.

Latvian state institutions (the Ministry of Economics, the Ministry of Environmental Protection and Regional Development, the State Construction Control Bureau), financial institutions (Altum) and housing managers themselves (the Association of Management and Administration of Latvian Housing (AMALH) recognise the need to accelerate the renovation of multi-apartment residential buildings by performing energy efficiency increase measures as one of the main components of climate change policy. The project therefore aims to promote the implementation of EU directives on residential renovation by developing and improving the study course programme for housing managers with climate change competences.

Accelerating the process of renovation of multi-apartment buildings requires special attention, support provided, as well as the necessary knowledge. The way to do this is to involve housing managers responsible for managing buildings in the process. However, these housing managers often lack the necessary knowledge and skills to launch and implement such projects. In order to address these shortcomings in Germany, the European Climate Initiative EUKI has already funded the KLIMAVERWALTER project, within the framework of which an innovative training scheme for acquiring the necessary skills by residential house managers has been developed 
and introduced. In the CLI-MA project, a new approach is planned to the transfer of knowledge from Germany, adapting it to the specific circumstances of Latvia.

\section{MANAGEMENT OF MULTI-APARTMENT RESIDENTIAL HOUSES}

The housing policy, as well as matters regarding the management of multi-apartment residential buildings in Latvia are under the responsibility of the Ministry of Economics. The goal of the housing policy is to promote the quality and accessibility of housing by providing the regulatory base for the efficient management of residential buildings, by facilitating the establishment of a rental residential fund in municipal areas and by supporting energy-saving measures in residential buildings ${ }^{[4]}$. As for 1 January 2020, the monitoring and control in the field of energy, including the administration of energy efficiency issues, shall be performed by the State Construction Control Bureau.
In total in Latvia, as of the beginning of 2021, there were 366532 residential buildings, of which 39426 were three- or more apartment buildings [5]. The highest proportion $-85.2 \%$ is for single-apartment or two-apartment buildings, i.e., $3.8 \%$, while three- and more apartment buildings make up $10.8 \%$ of the total number.

The total area of residential buildings is 91.1 million $\mathrm{m}^{2}$. When providing a breakdown by area (see Fig. 1), the largest proportion - 56.6\% is for three- and more apartment buildings, single-apartment buildings take up $40.1 \%$ of the total area of residential buildings, and two-apartment buildings and social group houses constitute $3.3 \%$.



Fig. 1. Breakdown of residential buildings by area (mil. $\left.\mathrm{m}^{2}\right)[6]$.

When analysing multi-apartment residential buildings by their construction year (Table 1), the bulk of them (44.6\%) were built until $1941 ; 13.6 \%$ of all residential buildings were constructed between 1941 and 1960; while the most houses (24.4\%) were built during the post-war years in 19611979. A further $13 \%$ of buildings were built between 1980 and 1992. However, buildings constructed after 1992 and the recovery of independence make up just $4.4 \%$ of the number of all residential buildings. 
Table 1. Breakdown of Buildings by Number of Floors and their Construction Year [6]

\begin{tabular}{|l|c|c|c|c|c|c|c|c|}
\hline $\begin{array}{l}\text { Houses/ } \\
\text { Years }\end{array}$ & $\begin{array}{c}\text { Until } \\
\mathbf{1 9 4 1}\end{array}$ & $\begin{array}{c}\mathbf{1 9 4 1 -} \\
\mathbf{1 9 6 0}\end{array}$ & $\begin{array}{c}\mathbf{1 9 6 1 -} \\
\mathbf{1 9 7 9}\end{array}$ & $\begin{array}{c}\mathbf{1 9 8 0} \\
\mathbf{1 9 9 2}\end{array}$ & $\begin{array}{c}\mathbf{1 9 9 3}- \\
\mathbf{2 0 0 2}\end{array}$ & $\begin{array}{c}\mathbf{2 0 0 3}- \\
\mathbf{2 0 1 4}\end{array}$ & $\begin{array}{c}\mathbf{2 0 1 5}- \\
\mathbf{2 0 1 9}\end{array}$ & Total \\
\hline $\begin{array}{l}\text { Multi-apartment buildings } \\
\text { with outer walls of wood }\end{array}$ & 8622 & 1472 & 472 & 77 & 20 & 34 & 7 & $\mathbf{1 0 7 0 4}$ \\
\hline $\begin{array}{l}\text { Multi-apartment 1-2-storey } \\
\text { buildings }\end{array}$ & 5257 & 2833 & 3057 & 638 & 91 & 226 & 26 & $\mathbf{1 2 1 2 8}$ \\
\hline $\begin{array}{l}\text { Multi-apartment 3-5-storey } \\
\text { buildings }\end{array}$ & 2644 & 918 & 5350 & 3385 & 243 & 597 & 63 & $\mathbf{1 3 2 0 0}$ \\
\hline $\begin{array}{l}\text { Multi-apartment 6-9-storey } \\
\text { buildings }\end{array}$ & 674 & 32 & 361 & 657 & 52 & 195 & 36 & $\mathbf{2 0 0 7}$ \\
\hline $\begin{array}{l}\text { Multi-apartment buildings } \\
\text { of 10 storeys and more }\end{array}$ & 0 & 0 & 172 & 264 & 23 & 72 & 9 & $\mathbf{5 4 0}$ \\
\hline Total & $\mathbf{1 7 1 9 7}$ & $\mathbf{5 2 5 5}$ & $\mathbf{9 4 1 2}$ & $\mathbf{5 0 2 1}$ & $\mathbf{4 2 9}$ & $\mathbf{1 1 2 4}$ & $\mathbf{1 4 1}$ & $\mathbf{3 8 5 7 9}$ \\
\hline Proportion, \% & $\mathbf{4 4 . 6 \%}$ & $\mathbf{1 3 . 6 \%}$ & $\mathbf{2 4 . 4 \%}$ & $\mathbf{1 3 . 0} \%$ & $\mathbf{1 . 1 \%}$ & $\mathbf{2 . 9 \%}$ & $\mathbf{0 . 4 \%}$ & $\mathbf{1 0 0 . 0 \%}$ \\
\hline
\end{tabular}

A majority of residential buildings have been operated for a considerable period of time, which means the necessity of gradual renovation of these buildings, while also improving their energy efficiency. In addition, the current depreciation of residential and non-residential buildings should be emphasised. According to the data provided by the State Land Service, the percentage of the total depreciation of residential houses is $38.9 \%$, while the depreciation of nonresidential buildings is $41 \%$ [6].

Until 1991, residential houses were built in accordance with the USSR construction standard "Thermotechnics of Building Envelopes" [6]. Construction of standard multi-apartment residential buildings was suspended after 1992. On 12 September 1991, Order No 68 of the Ministry of Architecture and Construction of the Republic of Latvia was issued on strengthening of requirements to building enclosure structures. In 2003, the construction standard LBN 002-01 "Thermotechnics of Building Envelopes" came into force, which imposed significantly stricter requirements for building enclosure structures.

In 2015, LBN 002-15 "Thermotechnics of Building Envelopes" (amendment LBN 002-01) entered into force. The amendments introduced even more stringent ther- motechnical requirements to building envelopes. On 11 November 2015, amendments were made to Cabinet Regulation No. 383 of 9 July 2013 "On the Energy Certification of Buildings", which set the minimum level of energy consumption for heating, both for renewable/reconstructable buildings and new ones, as well as requirements for the gradual transition of new buildings to nearly zero-energy buildings. Consequently, new requirements were created for the construction of buildings, as well as for reconstruction and renovation projects.

In 2020, the next amendments to the construction standard LBN 002-19 "Thermotechnics of Building Envelopes" came into force, which stipulated that all new residential buildings should have to be nearly zero-energy buildings as of 2021 [7]. In 2021, the Methods for Calculating the Energy Efficiency of Buildings and Energy Certification Regulations for Buildings were adopted, which replaced the Cabinet Regulations "On the Energy Certification of Buildings" and the "Method for Calculating the Building Energy Efficiency" [8]. The requirements of all these regulatory enactments are derived from Directive (EU) 2018/844 of the European Parliament and of the Council of 30 May 2018 amending Directive 2010/31/EU on the energy effi- 
ciency of buildings and Directive 2012/27/ EU on energy efficiency.

The final consumption of energy resources in Latvia in 2019 was 174.8 PJ. Households consumed 49.7 PJ, corresponding to $28.5 \%$ of the total final consumption [9]. Over the past 10 years, households have consumed $28-34 \%$ of the total national energy consumption, so the building sector has considerable potential to achieve the overall energy efficiency targets.

According to the State Construction Control Bureau, the average specific energy consumption for heating in multi-apartment buildings was $124 \mathrm{kWh} / \mathrm{m}^{2}$ per year in 2020 and $125 \mathrm{kWh} / \mathrm{m}^{2}$ per year in 2019 [10]. By 2030, Latvia has committed to ensuring a reduction in the average specific thermal energy consumption in buildings to $120 \mathrm{kWh} / \mathrm{m}^{2} /$ year [11]. According to the Ministry of Economics, more than 23000 buildings (in the multi-apartment building sector) would need to be renovated at the moment, but only $4 \%$ of these buildings have actually been renovated.

From 2021 onwards, the minimum level for energy efficiency of new buildings must comply with the requirements of a nearly zero-energy building (the average specific energy consumption of a residential build- ing for heating is not more than $40 \mathrm{kWh} / \mathrm{m}^{2}$ per year); for renovated and reconstructed multi-apartment buildings, the average specific energy consumption for heating must not exceed $80 \mathrm{kWh} / \mathrm{m}^{2}$ per year [7].

The Ministry of Economics states that the main problems in energy efficiency of buildings are:

- an outdated housing fund, including a low level of energy efficiency;

- low public activity and lack of interest in increasing building energy efficiency measures (bureaucratic procedures, low solvency);

- lack of information and insufficient level of education regarding the organisation and performance of energy efficiency measures for buildings;

- insufficient involvement of private investment (mostly EU structural funds and state funding are used) [6].

It can be concluded that multi-apartment residential buildings represent a significant part of the total residential area in Latvia, and most of these buildings have high energy consumption and significantly lower thermal performance than can be provided with currently available technologies [11].

\section{RESULTS AND DISCUSSION}

According to the Law on Administration of Residential Houses, each residential house must be ensured that it is properly operated, maintained and improved, as well as its continuous management process. A person is entitled to perform an administrative task in a multi-apartment building when having acquired the vocational education required for the management of residential buildings and a specified level of professional qualification.
Such an administrator should also plan energy efficiency improvement measures, including replacing depreciated elements or constructions, where the average thermal energy consumption of the building used for heating the building exceeds $150 \mathrm{kWh} / \mathrm{m}^{2}$ per year over the last three calendar years.

In order to clarify the opinion of current and potential employees in this sector, a survey was conducted regarding what skills, if any, are needed for a house administrator on 
energy efficiency of buildings and climate change issues.

The survey questions covered the following aspects:

- the experience and plans of respondents with regard to the implementation of measures to improve the energy performance of buildings;

- self-assessment of respondents as regards their competences for the implementation of energy efficiency measures for buildings;

- views of respondents on a complex approach to the implementation of measures to improve the energy performance of buildings related to the interaction between different aspects of the management of non-residential properties (technical, legal, financial, organisational, social, information exchange, etc.);

- the need for specific skills and competences in the planning and implementa- tion of technical, legal, financial, organisational, social, information exchange and other issues.

The survey involved 63 respondents, namely:

- members of the Association of Management and Administration of Latvian Housing (the Association of Management and Administration of Latvian Housing is a public organisation uniting natural and legal persons throughout the Republic of Latvia who are interested in achieving common objectives in the administration and management of real estate[12]),

- future housing managers studying at Riga Technical University.

A majority of the respondents (86\%) believe that in the future they will have to deal with the organisation of energy efficiency measures in buildings with a high probability (Fig. 2).

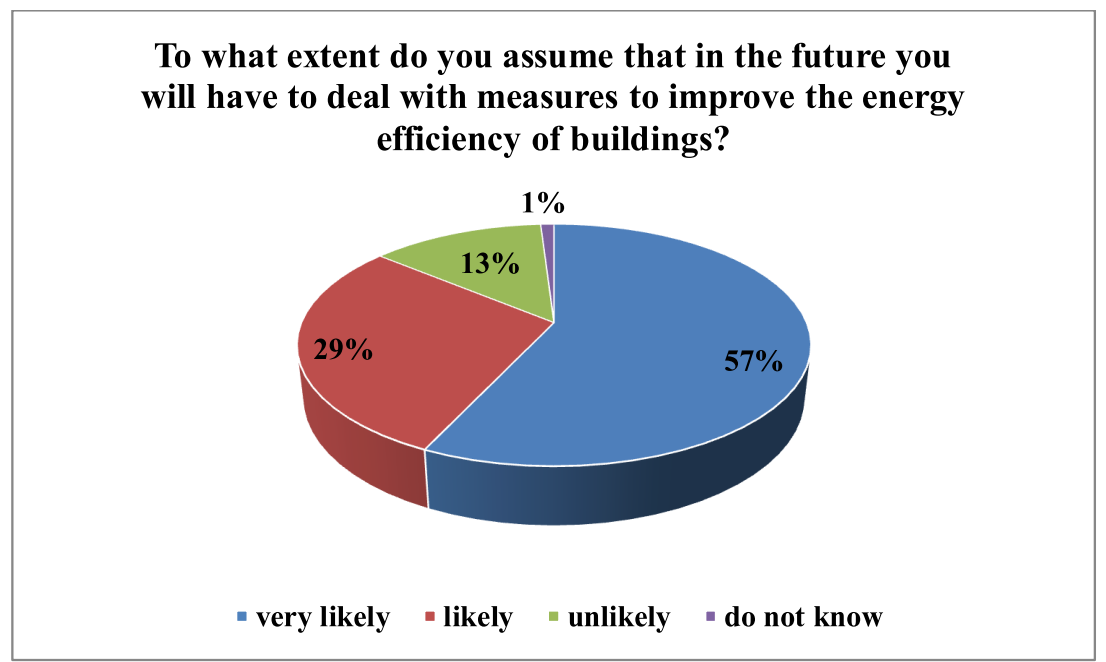

Fig. 2. Plans of respondents.

It should be noted that $39 \%$ of those surveyed have already participated in implementing energy efficiency measures at least once. Yet, more than $60 \%$ have never come across it (Fig. 3). 




Fig. 3. Experience of respondents.

Assessing their competences in the implementation of energy efficiency measures regarding financing issues, technical solutions, legal issues, organisational aspects and promotion of energy efficiency measures (Fig. 4), on average 15-30\% respondents consider them to be of high or sufficient qualifications, while 50-70\% consider their knowledge to be partial or insufficient. According to the survey, 10-20\% have self-assessment problems. The lowest level of assessment of existing competence is in the legal sphere, as well as in the search for technical and financing solutions.

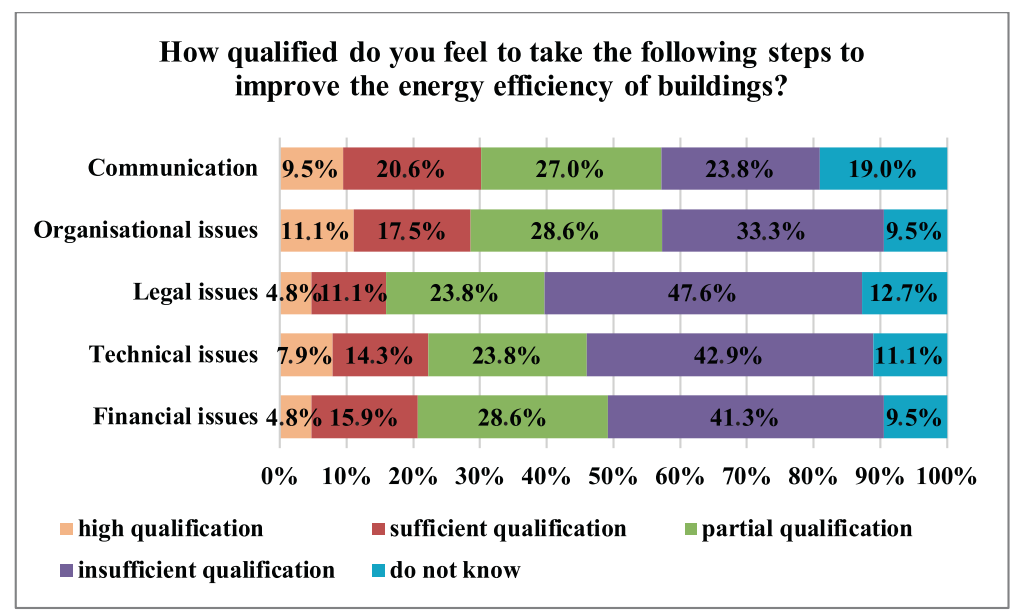

Fig. 4. Self-assessment of respondents.

All respondents (95\% fully and $5 \%$ partially) agree with the statement that the successful implementation of energy efficiency measures for buildings requires interaction between the various aspects of real estate management (technical, legal, financial, organisational, social, information exchange, etc.).
As far as technical knowledge is concerned, a convincing majority (82-92\% fully and about $6-16 \%$ partially; $98 \%$ in total) consider that successful implementation of measures to improve the energy efficiency of buildings requires knowledge and skills on at least the following issues: 
- Building microclimate;

- Construction physics of building structures;

- Energy efficiency of building envelopes;

- Energy efficiency of engineering communications of buildings;

- Energy efficient building materials.

Regarding issues on financial and economic knowledge, 70-80 \% fully and 16-27\% partly agree that the successful implementation of measures to increase energy efficiency of buildings requires at least the following:

- Investment in energy efficiency measures;

- Financial support instruments for energy efficiency measures;

- Economic evaluation of energy efficiency projects;

- Basic principles for setting up service tariffs.

$70-80 \%$ fully and 18-29\% partly agree that successful implementation of energy efficiency measures for buildings requires legal expertise on at least the following issues:

- the regulatory framework for energy efficiency and renewable energy;

- the regulatory framework for the construction processes;

- the regulatory framework for the administration of buildings;

- construction contracts;

- contracts on services (heating, water supply, electricity supply, etc.).

80-94 \% fully and 5-19\% partly agree that the successful implementation of energy efficiency measures for buildings requires organisational and management skills:

- in project management;

- in risk management;

- in planning energy efficiency and renewable energy measures.
Regarding communication skills, $83 \%$ of respondents fully and $17 \%$ partially acknowledge that minimum the following is needed:

- holding negotiations and meetings;

- solution of conflicts;

- cooperation;

- consultation;

- $\quad$ speeches and presentations.

Having summarised all of the obtained results, it can be concluded that:

1. The qualifications of existing and future housing managers are not sufficient and additional knowledge needs to be acquired;

2. The successful implementation of energy efficiency measures for buildings requires competences in different aspects of the administration of nonresidential properties (technical, legal, financial, organisational, social, information exchange, etc.), and therefore training should be developed to cover all these issues.

The knowledge required for housing managers to perform their duties and tasks by categories is provided in Fig. 5 .

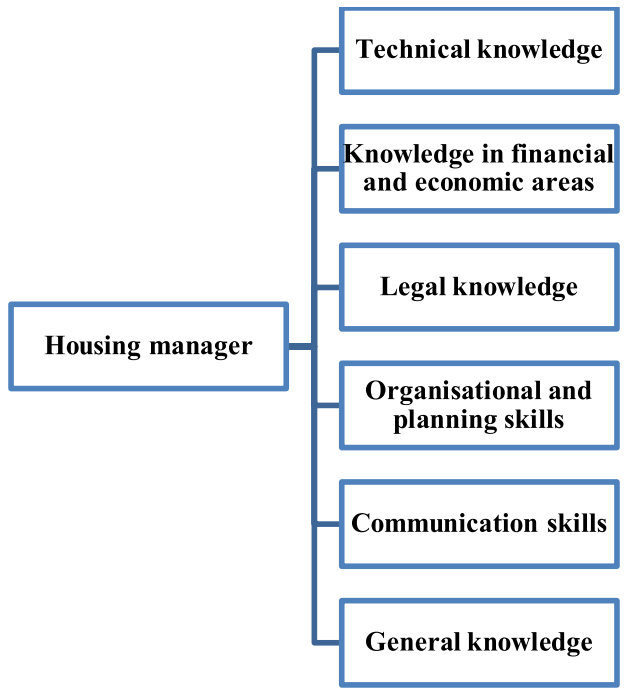

Fig. 5. Categories of required knowledge. 
In order to establish a high-quality and comprehensive programme for such training, it is necessary to develop a description of a housing manager with competence for climate change mitigation, including a description of the activities of the housing manager, key responsibilities and tasks, as well as the necessary skills, attitudes and resources to fulfil them. Having clarified the above issues, it is possible to define the necessary knowledge and competences for the successful performance of job responsibilities and tasks and to develop the necessary skills.

The methodology for the characterisation of the housing manager with competence to mitigate climate change is based on the structure of qualifications for the real estate management sector and complies with the Methodology for Developing the Requirements for Occupational Standards/Professional Qualification [13]. The description of the housing manager includes the following sections:

1. Brief activity description;

2. Basic duties;

3. Main tasks;

4. Skills required to fulfil basic duties and tasks

5. Knowledge (general and professional);

6. Required competences.

Schematically, the process of determining the required competences of housing manager is provided in Fig. 6.

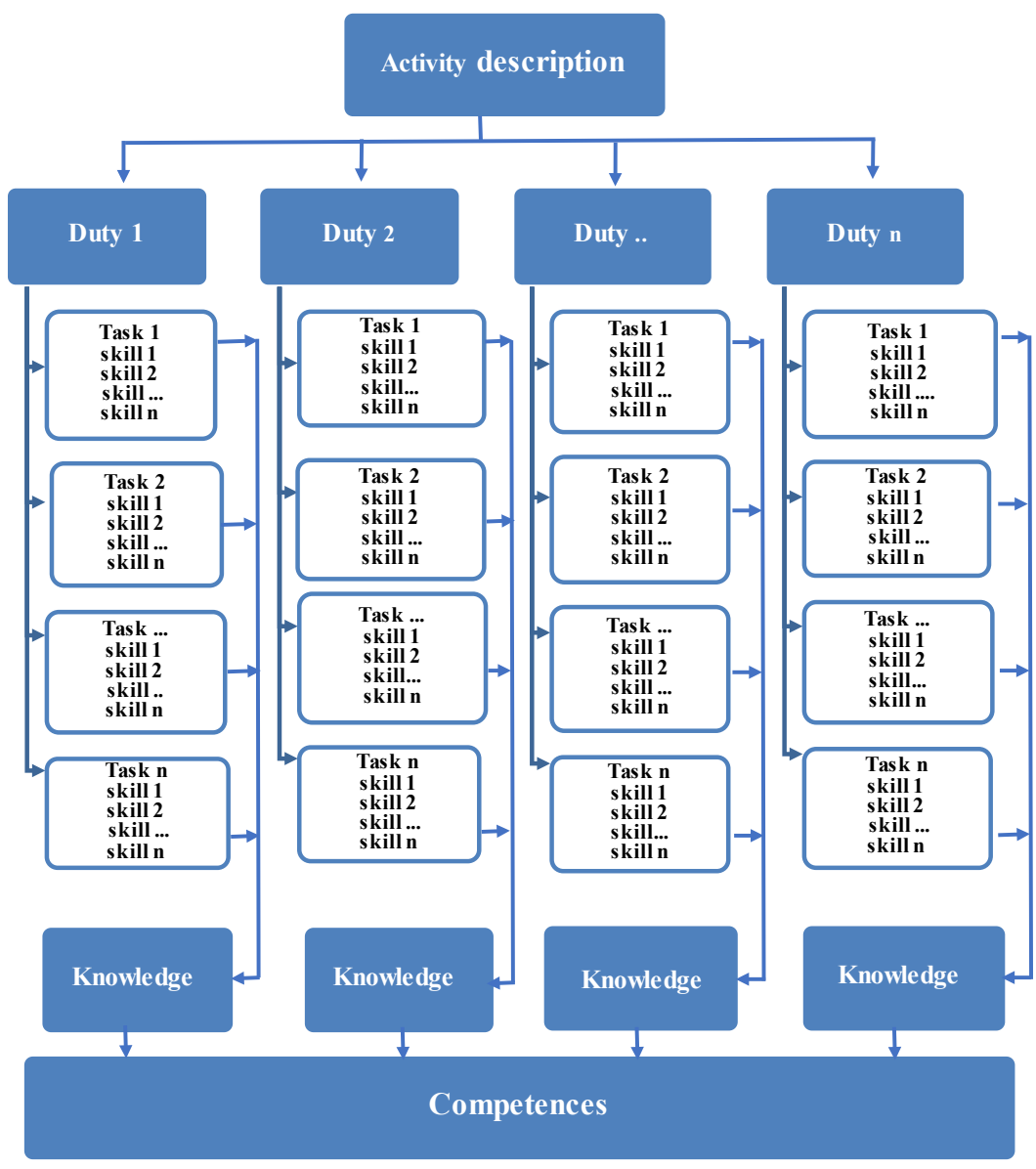

Fig. 6. Methodology for determining the required competences. 
The activity description provides information on the mission, key responsibilities, the environment in which the professional representative operates and the degree of responsibility.

Other characterising elements are defined below [13]:

- The obligation is a long-term work, which is a grouping of related tasks, which has no set start and end and which is difficult to measure.

- The task is a completed, measurable unit of work which ensures that an obligation is fulfilled in general.
- Skill is the ability to perform an activity according to the quality and extent required, and is a prerequisite for performance.

- Knowledge - a systematised set of objective concepts obtained through learning, work experience, research and the like; it results from cognition.

- Competence - the necessary knowledge, professional experience, awareness in a specific field, issue and skills to use knowledge and experience in a specific activity.

\section{CONCLUSIONS}

One of the problems identified in the policy documents developed by the Ministry of Economics (Latvian National Energy and Climate Plan for 2021-2030, the Longterm Strategy for Renewal of Buildings) in the field of energy efficiency of buildings in Latvia is an insufficient level of education regarding the organisation and performance of energy efficiency improvement measures for buildings.

The results of the survey conducted within the framework of the research confirm this statement, since the majority of respondents consider that the qualifications of housing managers are insufficient at the moment and that additional knowledge is needed.

In order to achieve the objectives set out in the Latvian development planning documents in the field of energy efficiency of buildings, the duly educated housing man- agers with competence in energy efficiency and climate change issues are required, who would be able to organise the implementation of energy efficiency measures and the appropriate maintenance of buildings after taking such measures.

The identification of the required competences requires the development of a description of the specific profession, including a description of the activities of the housing manager, the main duties, tasks and the necessary skills to further define the required knowledge and competences.

For the successful implementation of energy efficiency measures for buildings, housing managers need competence in technical, legal, financial, organisational, social, information exchange and other issues. The acquisition of these competences should constitute a training course programme covering all these aspects.

\section{ACKNOWLEDGEMENTS}

This research has been funded by the project "From Housing Manager to CLImate Manager". This project is part of the
European Climate Initiative (EUKI). EUKI is a project financing instrument by the German Federal Ministry for the Environment, 
Nature Conservation and Nuclear Safety (BMU). The EUKI competition for project ideas is implemented by the Deutsche Gesellschaft für Internationale Zusammenarbeit (GIZ) GmbH. It is the overarching goal of the EUKI to foster climate cooperation within the European Union (EU) in order to mitigate greenhouse gas emissions. Agreement number: 81263938, Project processing number: 17.9045.0-002.77

\section{REFERENCES}

1. Geipele, I., Kundziņa, A., Zvirgzdiņš, J., Pḷavinana, B., \& Stāmure, I. (2021). Market research among facility managers, public bodies and financing institutions in Latvia regarding the scope of existing and required skills of building managers on topics related to mitigation of climate change caused by buildings in Latvia. Riga: RTU.

2. Saeima. (2020). Latvian National Development Plan for 2021-2027 (NAP2027). Available at https://likumi. lv/ta/id/315879-par-latvijas-nacionaloattistibas-planu-20212027-gadam-nap2027

3. Eurostat. (2021). House or Flat-Owning or Renting. Available at https://ec.europa. eu/eurostat/cache/digpub/housing/bloc-1a. html?lang=en

4. Ministry of Economics. (n.d.). Housing. Available at https://www.em.gov.lv/en/housing

5. Valsts zemes dienests. (2021). Registrēto būvju skaits sadalījumā pa galvenajiem lietošanas veidiem. Available at https://www.vzd.gov. lv/lv/registreto-buvju-skaits-sadalijuma-pagalvenajiem-lietosanas-veidiem

6. Ministry of Economics. (2020). Informative Report "Long-term Strategy for Building Renovation". Available at http://tap. $\mathrm{mk}$.gov.lv/mk/tap/?pid=40487380

7. Cabinet Regulation No $280 . \quad$ (2019). Regulation on Latvian Construction Standard LBN 002-19 "Thermotechnics of Building Envelopes". Available at https://likumi. lv/ta/id/307966-noteikumi-par-latvijasbuvnormativu-1bn-002-19-eku-norobezojosokonstrukciju-siltumte
8. Cabinet Regulation No 222. (2021). Ėku energoefektivitātes aprēķina metodes un ēku energosertifikācijas noteikumi. Available at https://likumi.lv/ta/id/322436eku-energoefektivitates-aprekina-metodesun-eku-energosertifikacijas-noteikumi

9. Official statistical portal. (2020). Latvijas energobilance 2019. gadā. Available at https://admin.stat.gov.lv/system/files/ publication/2020-08/Nr_23_Latvijas energobilance_2019 gada \%2820_00\%29 LV.pdf

10. Būvniecības valsts kontroles birojs. (2021). Vidējais energoefektivitātes rādìtājs. Available at https://www.bvkb. gov.lv/lv/energoefektivitates-jautajumuadministresana

11. Cabinet Order No 46. (2020). Latvijas nacionālais enerḡétikas un klimata plāns 2021. - 2030. gadam. Available at https:// likumi.lv/ta/id/312423-par-latvijasnacionalo-energetikas-un-klimata-planu20212030-gadam

12. Association of Management and Administration of Latvian Housing. (2021). Available at http://www.Inpaa.lv

13. Valaine, S., Kaukule, H., Daņilova, T, Annuškāne, I., Vīgante, D., Strode, L.I., \& Braunšteins, B. (2017). Profesiju standartu /profesionālās kvalifikācijas prasību izstrādes metodika. Riga: National Centre for Education. 